\title{
Instructional Materials of Quadratic Equations for 10th Grade Indonesia Students: Combined Round Robin- Cooperative Learning and Problem Posing
}

INFO ARTIKEL

Diterima: 2-01-2020

Disetujui: 7-01-2020

Kata Kunci:

Development, Lesson

Plan, Round Robin,

Problem Posing.

\author{
Ahmad Isroil ${ }^{1,2}$, Hikmah Hakimah ${ }^{3}$ \\ ${ }^{1}$ Departement of Mathematics, Universitas Billfath \\ ${ }^{2}$ SMA Unggulan BPPT Al Fattah Lamongan \\ ${ }^{3}$ MA At Taraqi Malang
}

\begin{abstract}
Abstrak: Tujuan dari penelitian ini adalah mendeslripsikan proses pengembangan dan menghasilkan perangkat pembelajaran yang efektif dalam pembelajaran persamaan kuadrat di kelas X dengan pembelajaran kooeratif tipe Round Robin dengan pendekatan problem posing., dan juga mendeskripsikan keefektifan pembelajaran. Pendekatan problem posing membuat siswa dapat mengajukan permasalahan sesuai dengan materi yang diajarkan. Subjek penelitianini adalah guru dan siswa kelas $X$. design pengembangan perangkat pembelajaran menggunakan model Kemp (2011). Perangkat pembelajaran terdiri dari: (1) RPP, (2) LKS (3) THB. Perangkat pembelajaran yang dihasilkan memenuhi kriteria baik karena memenuhi: (1) valid; (2) praktis; (3) efektif.. Pada kelas implementasi juga didapatkan bahwa pembelajaran efektif. Hal ini dapat ditunjukkan dengan kemampuan guru dalam mengelola pembelajaran baik, siswa aktif dalam pembelajran, siswa memberikan respon positif pada pembelajaran, lebih dari $80 \%$ siswa memeroleh nilai diatas 70 .
\end{abstract}

\begin{abstract}
The purpose of this research is to describe the process of developing and producing effective learning tools for teaching quadratic equations in 10th grade by applying the Round Robin type of cooperative learning through posing problems, as well as to describe the effectiveness of the learning process itself. The problem posing approach allows students to utilize this knowledge when they encounter problems related to the materials being thought. The subjects of this research one 10th grade teacher and 10th grade students. The design of this study uses Kemp's model of research and development (2011). The developed learning tools consists of: (1) lesson plans, (2) student's worksheets, and (3) an achievement test. Based on descriptive analyses of the trial session, results show the lesson plan utilized was appropriate because it was: (1) valid; (2) practical; (3) effective. Based on descriptive results, the implementation session was also deemed effective. This conclusion is based on the conditions which indicate that the teacher's ability to organize learning was effective, the students were active during learning process, the students responded positively to the learning process, and over $80 \%$ of the students achieved grades of 70 or higher.
\end{abstract}

Alamat Korespondensi:

Ahmad Isro'il

Universitas Billfath

Komplek PP Al Fattah Siman Sekaran, Lamongan

Email: ahmadisroil@billfath.ac.id 
One of the learning strategies that is oriented to constructionist learning theory is cooperative learning. Cooperative learning there are various types of learning, one of which is Round Robin. Round Robin type cooperative learning model is a cooperative learning model in which students take turns contributing answers in groups (Teacher Companion, 2002). The heart of mathematics is to pose problems and solve (Brown \& Walter, 1990). The learning approach aims to make it easier for students to understand the material (Soedjadi, 2000). This is in accordance with the results of the study that the Student Activity Sheet and Student Activity Sheet make the students better understand the learning materials (Juniati \& Budayasa, 2017). Therefore, the problem posing activity become an important role in mathematical thinking and become an important part on problem solving. The giving assignments to the students to create questions could improve the ability to solve problems and their attitudes toward (Winograd, 1997). The problem posing could improve thinking skills, problem solving, attitude, confidence in solving problems, and generally contribute to the understanding of mathematical concepts (English, 1998). To develop the ability of mathematical problem posing, we required the ability to creating new questions, creating new opportunities, and looking at old questions from a new angle (Ellerton \& Clarkson, 1996). The relationship between creativity and posing problems does not stand alone but affects each other (Silver, 2013) After made questions, the students were asked to check the accuracy of the questions answered. These activities could train the students to think reflectively. Submission of core questions requires students to file or create new problems before, during or after completion of the initial problem given (Siswono, 2005)..

Problem posing is not only seen as a purpose of learning but also as a tool that can provide experiences for students to find and to create mathematical problems. This experience is still a bit possessed by students. According to the findings , advanced high school students had trouble posing good quality and novel mathematical problem (Van Harpen \& Sriraman, 2013). Some senior high school students had difficulties in posing problem or limited understanding of that (Jo \& Han, 2016). The problem posing performance of senior high students and the teachers was the low quality of the created problems (Igor, 2016).

One approach to learning in accordance with the principles of cooperative learning Round Robin type is a problem posing approach that provides opportunities for each student to express their opinions. The problem posing approach in learning requires students to ask questions or questions that match their interests based on the material given and think about how to solve them. Round Robin cooperative learning steps with problem posing approach: 1) group formation, 2) problem presentation, 3) problem making, 4) exchange of questions, 5) work on questions, 6) discussions, 7) discussion of questions. Learning tools in this study will include lesson plans, student's worksheets, and an achievement test. The design model of learning device development used in this research is the model proposed by Kemp (2011).

The purpose of this research are: 1) Describe the process and result of development of cooperative learning tool type Round Robin with problem posing approach on the material of quadratic equation for tenth grade students. 2) Describe the effectiveness of cooperative learning type Round Robin with problem posing approach on the matter of quadratic equation for tenth grade students.

\section{METHOD}


KARANGAN: Jurnal Kependidikan, Pembelajaran, dan Pengembangan, Vol 02, No 01, Bln Feb, Tahun 2020, Hal 1 - 6

The type of this research is research development. The research was conducted on the students of class X MA Nurul Ulum Malang academic year 2017/2018. Learning device test is done in class X IPA 2, while effectiveness test is done in class X IPA1. The stages of learning device development is identification of learning problem; analysis of student characteristics; task analysis; formulate learning objectives; material order; determining learning strategies; determine teaching methods; media learning; developing evaluation instruments (Morrison, Ross \& Kalman, 2011).

The instruments used in the development of Round Robin type cooperative learning tools with problem posing approaches on the matter of quadratic equations are instrument of assessment of learning device, teacher's observation sheet, student activity observation sheet, student response questionnaire and test of learning to result. While the data collection technique is by disseminating the learning device validation sheet, observing the ability of the teacher in managing the learning, observing one group of students, distributing student response questionnaires, and giving test result of learning to the student.

The pilot activity is conducted to find out whether the learning device meets the valid, practical and effective criteria. Valid views of the validity of the content and validity of the construct, practically seen from the results of validator assessment that states that learning tools can be used as well as students and teachers easy to use, while effective views of positive student responses and achievement of student learning outcomes (Nieven, 1999). Descriptive data analysis methods include (1) data analysis of device validation results obtained from validator assessment, (2) data analysis of the teacher's ability to organize learning, which is said effective when the teacher's ability to organize learning has reached the minimum criteria either nalysis of student activity data, which is said to be effective if all kinds of student activities reaches the minimum criteria good, (4) analysis of student response data, which is said positive if the percentage of positive response every aspect $>80 \%$, (5) data analysis test; (a) validation of the test, which is said to be valid if it has a good minimum validity, (b) the reliability of the test, which is said to be reliably if it has a minimum degree of moderate reliability, (c) sensitivity, said to be sensitive to learning if the sensitivity value $S>0.30$.

Learning tools are said to be good if the learning tools meet three aspects, namely (1) validity, shown based on the validators assessment, the test results meet the criteria of validity of the matter minimal enough, moderate reliability, sensitivity $S>0.30$ (2) practicality, With that the teacher's ability to organize learning was effective and the students were active during learning process, (3) effectiveness, which is shown by the students responded positively to the learning process and over $80 \%$ of the students achieved grades of 70 or higher. Round Robin cooperative learning with problem posing approach is effective if it meets the criteria: (1) the teacher's ability to organize learning was effective, (2) the students were active during learning process, (3) the students responded positively to the learning process (4) over $80 \%$ of the students achieved grades of 70 or higher

\section{RESULTS AND DISCUSSION}

Stages of developing Kemp modeling tools: identification of learning problems; Analysis of student characteristics; Task analysis; Formulate learning objectives; Material order; Determining learning strategies; Determine teaching methods; Media learning; Developing evaluation instruments. Based on the data analysis of the stages in the Kemp device development model, the learning tool designed is a cooperative learning tool with Round Robin type with problem posing approach on 
the matter of quadratic equations. Learning to tool in the form of Learning Implementation Plan, Student Activity Sheet, and Test of Learning to result. Lesson Plans and Student Worksheets are designed for three meetings with 2 x 45 minutes for each meeting. The evaluation instrument is designed only to assess the cognitive domain only and the question form used is 10 description questions.

In this development study, revisions are conducted at each stage based on inputs and assessments obtained from validation activities. For validation learning devices declared valid by the validators so that learning devices can be used with a little revision. The results of the analysis obtained from the device trials are: (1) the teacher's ability to organize learning learning of each indicator of observation is in good and excellent category, (2) student activity of each observation indicator is in good and excellent category, (3) The percentage of students who chose the positive statements category was more than $80 \%$, and (4) over $80 \%$ of the students achieved grades of 70 or higher (5) the learning result test was valid, reliablle, and sensitive. These criteria can be seen in the table below:

Table 1. Achievement of a good learning to tool citeria

\begin{tabular}{|c|c|c|}
\hline Aspect & Description & Results \\
\hline \multirow[t]{2}{*}{ Validity } & Assessment of learning tools by validators & valid \\
\hline & Test Results Learning & valid, reliable, sensitive \\
\hline \multirow[t]{2}{*}{ Practicality } & $\begin{array}{l}\text { The teacher's ability to organize learning } \\
\text { learning }\end{array}$ & good \\
\hline & Student activity during the learning process & Active \\
\hline \multirow[t]{2}{*}{ Effectiveness } & Student response to instructional devices & Positive \\
\hline & $\begin{array}{l}\text { over } 80 \% \text { of the students achieved grades of } \\
70 \text { or higher }\end{array}$ & Pulfilled \\
\hline
\end{tabular}

In relation to the students' ability to make the questions based on the information provided, the average problem students make has a low and moderate complexity. This is because the task of making a problem (problem posing) in the learning of mathematics is still relatively new for students is even a first experience for them.

\section{SOAL DARI KELOMPOK: 3}

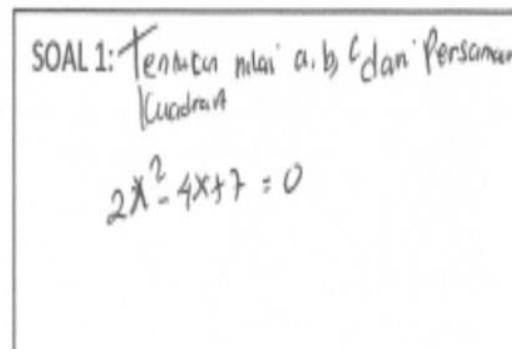

Figure 1. Sample Problem With Low Complexity
SOAL DARI KELOMPOK: ..4.

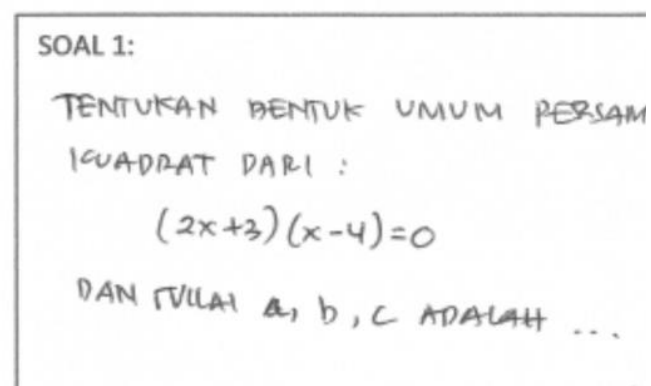

Figure 2. Sample Problem With Moderate Complexity

From figure 1 and figure $\mathbf{2}$ can be seen that there are problems made by students belonging to low complexity, because the solution is only directly using existing 
KARANGAN: Jurnal Kependidikan, Pembelajaran, dan Pengembangan, Vol 02, No 01, Bln Feb, Tahun 2020, Hal 1 - 6

data, without having to process data or use the procedure. On the question the students are only asked to mention the coefficients a, b, and c. While the problem with moderate complexity requires several procedures in the settlement.

In the effectiveness test, there are four types of data collected, namely: (1) the teacher's ability to organize learning, (2) the students were active during learning process, (3) the students responded positively to the learning process, and (4) over $80 \%$ of the students achieved grades of 70 or higher The results of data analysis can be seen from the following table:

Table 2. Achievement of effectiveness of learning in implementation class

\begin{tabular}{lll}
\hline No & \multicolumn{1}{c}{ Description } & Results \\
\hline 1 & The teacher's ability to organize learning & Effective \\
\hline 2 & The students were active during learning process, & Active \\
\hline 3 & The students responded positively to the learning process & Positive \\
\hline 4 & Over $80 \%$ of the students achieved grades of 70 or higher & Fulfilled \\
\hline
\end{tabular}

From table 2 it can be seen that cooperative learning type Round Robin with effective problem posing approach to teach the matter of quadratic equation for tenth grade students.

\section{CONCLUSION}

Based on data analysis and discussion of research result of cooperative learning type Round Robin with problem posing approach obtained some conclusions as follows: (1) The design of this study uses Kemp's model of research and development (2011), generated Round Robin type cooperative learning tool with problem posing approach consisting of lesson plans, student's worksheets, and an achievement test, (2) The learning tools developed meet the criteria of good tools after passing validation, test legibility and trial. This can be seen from the achievement of the criteria of a good learning tool, namely: (a) validity: learning tools declared valid by the validators and the test results of learning meet the criteria of valid, reliable, and sensitive (b) practicality: the teacher's ability to organize learning was effective, the students were active during learning process, (c) effectiveness: the students were active during learning process, the students responded positively to the learning process, and over $80 \%$ of the students achieved grades of 70 or higher (3) Round Robin type cooperative learning with effective problem posing approach to teach the material of quadratic equation, this is proved by the fulfillment of the requirements of the effectiveness of learning, namely: (a) the teacher's ability to organize learning was effective, which demonstrated the ability of teachers to manage learning from each observation indicator is In both good and excellent categories, (b) the student activity of each observation indicator is in both good and excellent category, (c) Student's response to positive learning, as indicated by the percentage of students choosing the agreed category and strongly agreeing to each aspect of the response of more than $80 \%$, (d) over $80 \%$ of the students achieved grades of 70 or higher 


\section{DAFTAR RUJUKAN}

Brown S I \& Walter I 1990 The Art of Problem Posing (2nd ed) (Hillsdale, N $\mathrm{J}:$ Lawrenoe Erlbaum Associates)

Ellerton N F \& Clarkson P C 1996 Language Factor in Mathematics Education (Alphen aanden Rijn: Academic Publisher)

English L 1998 Children's Problem Posing Within Formal and informal Context Journal for Research in Mathematic Education 29(1) p 83-106

Igor K 2016 Considerations of Aptness in Mathematical Problem Posing: Students, Teacher, and Expert Working on Billiard Task Far East Journal of Mathematical Education 16(3) p 243-260

Joo H \& Han H 2016 The Analysis of Middle School students' Problem Posing Type and Strategies The Mathematical Education 55(1) p 73-89

Juniati D \& Budayasa I K, 2017 Developing Experiment-Based Teaching Materials of Fractal Geometry to Upgrade Students' Competencies. http://www.researchgate.net/publication/315108644

Morrison G R, Ross S M, \& Kalman H K dan Kemp J E 2011 Designing Effective Instruction, (New York: Macmillan Collage Publishing Company).

Nieven, N 1999 Design Approch and Tools in Education and Training (Boston: Kluwer Academic Publisher)

Silver E 2013 Problem Posing Research in Mathematics Education: Looking Back, Looking Around, and Looking Ahead educational Studies in Mathematics 83(1) p 157-162

Siswono T Y E 2005 Upaya Meningkatkan Kemampuan Berpikir kreatif Jurnal Pendidikan Matematika dan Sains p 1-9

Soedjadi R 2000 Kiat Pendidikan Matematika di Indonesia: Konstatasi Keadaan Masa Kini Menuju Harapan Masa Depan (Jakarta: Dirjen Dikti Depdiknas)

Teacher Companion 2002 Teaching/Learning Companion (Ontario: Ministry of Education)

Van Harpen X Y \& Sriraman B 2013 Creativity and Mathematical Problem Posing: an Analysis of High School Students' Mathematical Problem Posing in China and the USA Educational Studies in Mathematics, 82(2) p 201-221

Winograd K 1997 Ways of Sahring Student-Authored Story Problems Teaching Children Mathematics 4(1) p 40-49 